\title{
Grice Maxim Violation in Schizophrenic Patients' Speech
}

\author{
Dindadari Arum Jati, Mohammad Umar Muslim, Uti Aryanti \\ Department of Linguistics \\ Faculty of Humanities, \\ Universitas Indonesia \\ Universitydindadari.daj@gmail.com, Universitymohammad_mslm@yahoo.com, Universityuti.aryanti@gmail.com
}

\begin{abstract}
The objective of this research is to classify the Grice maxim violation in schizophrenic patients' speech. This research uses the Grice Cooperative Principles to analyze how hebephrenic schizophrenia patients perform a communication. Previous research has been done in Europe by Barch dan Berenbaum (1996, 1997) and Berenbaum, Kerns, Vernon and Gomes (2008). However, the same research has not been done in Indonesia. In addition there has been no research which use comparison of schizophrenia patientsphase as a determinant variable.The data of this research are collected by interviewing the six hebephrenic schizofrenia patients (three acute and three quiet phase patients). The data are the transcribed and analyzed using the Cooperative Principles theory from Grice. From the analysis it is found that the most frequently violated maxim is maxim of relation. Patients with hebephrenic schizophrenia in the acute phase do more violations than those in the quiet phase. From the total 70 violations of maxim of relation, 49 times occur in the utterances of patients in the acute phase and 21 timesoccur in those in the quiet phase.
\end{abstract}

Keywords-hebephrenic schizophrenia, maxim infringement, Grice's Cooperative Principles

\section{INTRODUCTION}

Schizophrenia is cognition impairment which causes exaggerate suspicion, halusination and delusion which has impact in patients' utterance coherency (Boyle 2002). In Diagnostic and Statistical Manual of Mental Disorders (2000), Schizophrenia is classified into five types. Those five types are catatonic, hebephrenic, residual, paranoid, and unspecified. In addition, schizophrenics are categorized into four phases, namely prodromal phase, acute phase, quiet phase, and recovery phase. Among schizophrenia types, hebephrenic type is a type which shows disruptions of discourse planning. In Diagnostic and Statistical Manual of Mental Disorders (2000) mentioned that people with hebephrenic schizophrenia have prominent linguistic features, namely irregular speech (disorganized speech), uncertain talks (rambling) and reiterated phrases, and incoherent sentences.

those are by Barch dan Berenbaum (1996, 1997) and Berenbaum, Kerns, Vernon and Gomes (2008). However, the same research has not been done in Indonesia. In addition there has been no research which compares schizophrenia patientsphase as a determinant variable. There is research that has been done by Aini in 2015 about schizophrenic speech (all types and without age limit). The results of these studies show that speech and writings made by informants are far from perfect sentences. Informants are also unable to form a unified discourse. This is reflected in the absence of markers of cohesion and coherence. However, because the criteria of informants are less specific and not all informants are schizophrenic with the same type, then the results of the research can not be used as a general benchmark. In addition, there is also a case study research of schizophrenic patient conducted by Nugroho in 2014 that analyzed Tony Blank's speech based on the cooperative principle from Grice. From the research it can be seen that Tony Blank violated the maxim of quantity the most. This research is well targeted because it examines the unfamiliarity of speech by using the theory of Grice, but because the informant used as the data source is only one, it cannot be used as a main benchmark in researching the unfamiliarity of schizophrenic speech in Indonesia. From several studies that have been done above, we took the initiative to examine patients with schizophrenia by considering some aspects that were not included in previous researches, namely the number of patients who are not just one (case study), but six patients by giving a restriction of the patient's criteria based on the type and phase that the patient is suffering from. This research uses the Cooperative Principles theory of Grice as a tool to analyze the data. Specifically, this study will identify and classify what maxims are violated by hebephrenic schizophrenia both in the acute and quiet phase.

\section{METHOD}

The process of collecting data is done by interviewing six patients which are divided into two phases, three from acute phase (Ro, In, Yo) and three from quiet phase (Si, To, Da). Researchers sort out the informants in the acute and the quiet phase based on the criteria that have been determined by the mental hospital. In addition, the six patients interviewed were six different patients. For retrieving the data, researchers prepare five mandatory questions and some free questions. The recording procedure requires the licensing of the doctor in charge at the mental hospital. Thus, the interview is done approximately 20 to an hour. However, the transcribed data is the recording with only 20 minutes long.

After interviewing the informants, we transcribed the recording. The data obtained through the recording is transcribed in Indonesian spelling with the provision of transcript as Cutting put forward in his book Pragmatics and Discourse (2008). 
The transcribed data are then analyzed using the theory of the violation type by Grice in both phases. After the data is analyzed, calculations are performed for each phase of quiet and acute phase. After getting the number of violation type done from each phase, we compare the results and make a conclusion from the comparison of the violation number obtained.

The concept used to analyze data is the concept of cooperative principles summarized in four maxim from Grice which is mentioned in Grice(1991. p. 305-315), that is maxim of quality, of quantity, of relation, daan of manner:

A. The maxim of quality is the maxim which expects the speaker to say the truth, to say what they feel which is correlated with the reality.

B. The maxim of quantity is the maxim which expects the speaker to say something informative but not excessive.

C. The maxim of relation is a maxim which expects the speaker to say something relevant from the previous speech.

D. The maxim of manner is the maxim which expects the speaker to say something clearly and unambiguously.

A. Total Findings

\section{FINDING AND DISCUSSION}

From 20 minutes interview transcripts to six informants, this research found 124 total violation, both from the quiet phase and the acute phase. The breakdowns were 70 times from maxim of relation violations, 41 times from maxim of quantity violations, 8 times of maxim of manner violations, and 5 timesfrom maxim of quality violations. In other words, the most violated maxim is maxim of the relation, that is 70 times out of 124 total occurrences. The second violation is maxim of quantity which reach 41 times, then the third is maxim of manner and the last is the maxim of quality that appears 5 times out of 124 total occurrences.

\section{B. Maxim Violation}

From the analysis of the data, we found that the most violated maxim is the maxim of relation that reached 49 times of 84 total occurrence in the patients of acute phase. The details each is brokendown to 19 maxim of relation violationby Ro, 15 by In, and 16 violation by Yo. In addition, there are 21 times out of 40 total occurrences of the quiet phase. Ta and Da were doing each of them 8 maxim of relation violations, and Si committing 5 violations.It can be seen that acute phase schizophrenia violate the maxim of relation the most which indicates the lack of interest in responding to the relevant speech of the partners as in the findings below:

P : : Kalau kata ibu Mas Roni kenapa? (what did your Mom say about you?)

I :Nggak apa-apa (I am just fine)

P :Kalau kata dokter krisman kenapa? (What did dr. Krisman say about you?)

I :Aku ngajar akuntansi (I thaught accounting)

The example from the above dialog shows that there is no relation between the answer and the question. Just like the maxim of relation violations, I answered the question randomly. The context of the above conversation is $\mathrm{P}$ wants to ask what happened to I so that I can be admitted to the mental hospital, but the answer is out of the context. I give an answerthat is not discussed earlier. Another example comes from the quiet phase as the dialogue below:

P : :Oohh.. Bapak sendiri aja di Jogja? (So, You're alone in Jogja?)

I $\quad$ :Nggak, sama kakak.. (No, with my brother)

P $\quad$ :Oh sama kakak.. Dulu dari Makassar ke Jogja tahun berapa pak? (Well, with your brother.. In what year did you come to Jogja then, Sir?)

I :Ayah saya orang makassar (My Father is a Macassarese)

Similar to the previous example, I answers irrelevantly to the last questions. P tries to get information about the year he came to Jogja, but I answers it with the information about his father which is a Macassarese. It is obvious that from the discourse I performed is irrelevant. It indicates a jumping ideas which is produced by I to respond P's question.

The second maxim which is violated the most is maxim of quantity by acute phase, that is 31 times (Ro 8 times, In 12 times, and Yo 9 times violation) and maxim of manner by quiet phase which occurs 8 times (Ta commits 4 violations, Da 4 violations and Si does not commit maxim of manner violation). In the acute phase, the maxim of manner violation is not found at all, whereas for the occurrence of maxim of quantity violation by quiet phase only reaches 8 times (Ta commits 2 violations, Si commits 6 violations and Da does not commit maxim of quantity violation at all). The maxims that are least violated by both phases are the maxim of quality and the maxim of manner, while the acute phase violates the maxim of quality four times (each informant performs a maxim of quality violation), while for the quiet phase occurs only once by Si. Here is the example from the acute phase: 
P :Boleh ngerokok di sini? (You can smoke here?)

I :Boleh.. nggak apa-apa. Tapi nggak krusial buat aku sih. Jadi ya rokok satu bungkus bisa. (Yes, that'a fine. But it's not crucial for me. So I can smoke a pack a day)

Based on the maxim of quantity violation previously described, with answers that exceed require information is one of the indications. With the answer "yes, that's fine" is already sufficient to answer questions from $\mathrm{P}$ but how do I respond to the question provides information that is not asked by $\mathrm{P}$. So the above dialogue is classified as the maxim of quantity violation. More example of maxim of quantity example from the quiet phase is presented below:

$\mathrm{P} \quad$ :Di jawa timur udah berapa tahun berarti pak? (How long have you been in east Java?)

I :Jaman saya kuliah (When I was in a college)

The dialogue above seems quite relevant since P asked for the time and I answer "a time" but I implisitly tries to give more information to P that he was a college student back then. With those answer given I unconciously violates the maxim of quantity, since he exaggerates the answer.

The next maxim violation is the maxim of quality found 4 times the occurrence of 84 total maxim of violations. The maxim of quality violation done by the acute phase informant indicates that the ability to manipulate the information conveyed or the act of rejecting what has happened to him still exists or even provide information according to what he believes such as delusions and hallucinations, although not dominant. Examples of maxim of quality violations performed by the acute phase are as below:

$\mathrm{P} \quad$ : Emang stressnya gimana pak? (What kind of depression do you feel?)

I $\quad$ : Aku itu waras mbak, tapi stress. (I am healthy, just depresed)

The maxim of quality violation in the dialogue is seen from the answer given by I to answer the question P. The context of the dialogue is I explained that he was sentenced of "stress" by the hospital so it must be hospitalized in the asylum. But I feel that he is okay, so that raises a contradictory speech like above. The statement is a rejection that he suffered from schizophrenia and claimed that he was still "sane" and just "stress". If you look at the facts that exist, if I just stress, then the doctor will only provide outpatient medication and weekly control advice. But for the case of "stress" that has been suggested for hospitalization is usually more than just a regular stress and requires special handling. When compared between field facts and statements I, it appears that I tries to make a fake imaging that I was consciously spoken to his partner P. Therefore, the above dialogue is included in the maxim of quality violation. Here is another example from quiet phase which commits the maxim of quality violation:

P : : Stress gimana itu? (What kind of depression do you suffer?)

I $\quad$ : ya aku sebenernya nggak apa-apa.. (I am actually fine)

Just like the previous example, the above conversation is a maxim of quality violation. The maxim of quality is indicated by a statement that is difficult to verify. In a mental hospital setting it is hard to believe that someone who is sentenced to be a patient is fine. Because the verdict fell from the doctor in charge of the mental hospital and gave a verdict on a person as a schizophrenic is not an easy thing. Like other diseases, schizophrenia should also be treated until the patient can socialize with relatives and family back as usual. If I state that he is "okay" consciously, then I has violated the maxim of quality because I states things that are difficult to prove for context and setting like in a mental hospital and he is a patient.

The next maxim that will be elaborated is the maxim of manner. The maxim of the manner is the maxim which is not at all violated by the acute phase patient. In the data analyzed there is no single maxim of manner violation in hebephrenic schizophrenia patients in theacute phase. This indicates that in the acute phase, symptoms of giggling do not appear and more to the character of disorganized speech only.

Of all the features mentioned in the Diagnostic and Statistical Manual of Mental Disorders (2000), the most prominent features of language in the acute phase are symptoms of disorganized speech and rambling and non-coherent. The giggling symptoms indicated by the appearance of maxim of manner abuses are not found at all in the acute phase of phlebophrenic type schizophrenia.

Slightly different from the acute phase. The dominance of maxim of relation violations in people with quiet phase schizophrenia is not surprising that it reaches 21 heads from the total occurrence: Here is the example of the maxim of manner violation which is only found in the quiet phase:

$\mathrm{P} \quad$ : Emang di rumah nggak ada tawon? (Is there no bee in your home?)

I : Hihihihihihih 
The maxim violation of the manner happen when the response is an unclear, ambiguous and unsuitable expression. This is in accordance with the example above dialog. I answer questions from his partner $(\mathrm{P})$ with giggling. It gives an indication of the unclear and ambiguous expression of a question. The dialog before the dialogue above is a context that I explained about his urge to go home immediately because in the Mental Hospital there are a lot of bees. If I answer the question with "No", actually the maxim of violation of the manner will be not happened. Seeing the response given I do not agree with the principle of cooperation of Grice especially in the maxim of manner, therefore, the above dialogue is included in the maxim of the manner violation

\section{CONCLUSION AND RECOMMENDATION}

The two most prevalent maxim which are violated indicates that what is written in the Diagnostic and Statistical Manual of Mental Disorders (2000) meets the general characteristics of hebephrenic schizophrenia in the form of disorganized speech production as well as unambiguous and uncertain conversations real presence for informants both in the phase of quiet and the acute phase. In addition, other common characteristics of schizophrenia such as giggling are also seen from 8 maxim of violations of the manner produced by the informant.

The findings in the acute phase meet the general characteristics of hebephrenic schizophrenia in the form of production of disorganized speech (disorganized speech) as well as the conversation that is uncertain (rambling) and not solid. Given the smallscale appearance of a maxim of quality violation, it indicates that the acute phase still has a lot of wisdom that makes it difficult to prove or even unreal.

By looking at data that has been analyzed, quiet phases tend to violate all maxims. Maxim of manner, that is not found in the acute phase, is found in the quiet phase which gives a new view of the general symptoms of schizophrenia, a newly emerging phenomenon when it has entered a quiet phase. However, the average number of occurrences of violations in the quiet phase is relatively fewer than the acute phase.

This indicates that the phase is still very influential on the speech which is produced by the schizophrenic patients at Puri Nirmala Hospital Yogyakarta. It can be seen from the maxim of relation and the quantity of the most violated indicates that the patient's speech still meet the general characteristics of people with schizophrenia which is mentioned in the Diagnostic and Statistical Manual of Mental Disorders (2000).

In addition, the emergence of common features such as giggling which is only found in the quiet phase also indicates the need of re-evaluation the general characteristics of the Diagnostic and Statistical Manual of Mental Disorders (2000) or even phase classification. However, when it is viewed from the number of findings, it tends to be relatively small in the quiet phase, it is worth to re-evaluate for the grouping of general characteristics of schizophrenic hebephrenic type both in the acute phase and the quiet phase.

Due to the limitation of the research, the researchers do not the type of the violation that will be really helpfull to the advance conclusion. Moreover, the research is only done in Yogyakarta, then it is better if the next researcher can do the research in the three major city in Indonesia which has the highest number of the schizophrenia patients due to the result of the data validation.

\section{References}

Aini, Miza Rahmatika. (2015). Pola Bahasa pada Penderita Skizofrenia. Tesis tidak diterbitkan. Yogyakarta: Universitas Gadjah Mada.

Barch, D.M., \& Berenbaum, H. (1997). The Effect of Language Production Manipulations on Negative Thought Disorder and Discourse Cohherence Disturbance in Schizophrenia. Psychiatry Research,71, 115-127.

Berenbaum, H., Kerns, J.G., Vernon, L.L., \& Gomez, J.J. (2008). Cognitive Correlates of Schizophrenia Signs and Symptoms: I. Verbal Communication Disturbance. Psychiatry Research, 159, 147-156.

Boyle, M. (2002). Schizophrenia: A Scientific Delusion? ( $2^{\text {nd }}$ Ed.). New York: Routledge.

Cuttng, J. (2002). Pragmatics and Discourse. Londo and New York: Routlege

Maramis, W.(1990). Catatan Ilmu Kedokteran Jiwa. Surabaya : AUP

Nugroho, Wahyu Wiji. (2014). Karakteristik Bahasa Toni Blank (Seorang penderita skizofrenia). Tesis tidak diterbitkan. Yogyakarta: Universitas Gadjah Mada.

Roan, W. (1980). Ilmu Kedokteran Jiwa. Jakarta : EGR

Sadock, B. J., Sadock, V. A., \& Ruiz P. (2015). Synopsys of Psychiatry: Behavioral Sciences/Clinical Psychiatry Eleventh Edition. New York: Wolters Kluwer.

Sperber, D dan Wilson, D. (1986). Relevance: Communication and Cognition. Cambridge: Harvard University Press.

Sperber, D dan Wilson, D. (1995). Relevance: Communication and Cognition $2^{\text {nd }}$ Edition. Cambridge: Harvard University Press. Sugiyono. (2008). Metode penelitian kuantitatif kualitatif dan $r \& d$. Bandung: Alfabeta.

Suryani, Y. (2016, Juni). Defisit Tindak Tutur Penderita Skizofrenia di RS Jiwa Menur Surabaya: Studi Kasus Pada Pasien MR. Makalah Prosiding Seminar Tahunan Linguistik UPI: Linguistik Forensik untuk Keadilan. 